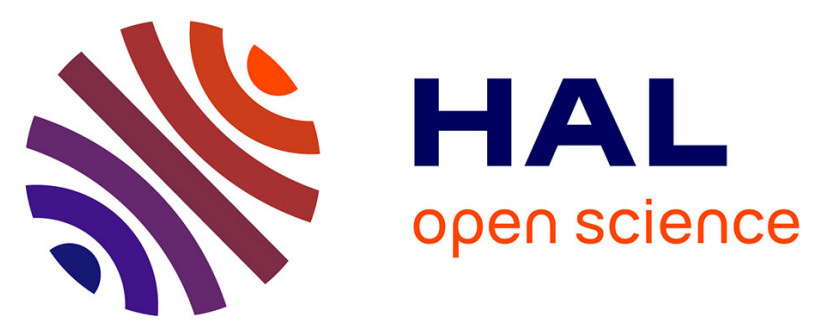

\title{
Valorization of industrial wastes from French maritime pine bark by solvent free microwave extraction of volatiles
}

Hamid Mellouk, Alice Meullemiestre, Zoulikha Maache-Rezzoug, Bouchra Bejjani, Adil Dani, Sid-Ahmed Rezzoug

\section{To cite this version:}

Hamid Mellouk, Alice Meullemiestre, Zoulikha Maache-Rezzoug, Bouchra Bejjani, Adil Dani, et al.. Valorization of industrial wastes from French maritime pine bark by solvent free microwave extraction of volatiles. Journal of Cleaner Production, 2016, 112, pp.4398_4405. 10.1016/j.jclepro.2015.06.129 . hal-02637301

\section{HAL Id: hal-02637301 https://hal.inrae.fr/hal-02637301}

Submitted on 27 May 2020

HAL is a multi-disciplinary open access archive for the deposit and dissemination of scientific research documents, whether they are published or not. The documents may come from teaching and research institutions in France or abroad, or from public or private research centers.
L'archive ouverte pluridisciplinaire HAL, est destinée au dépôt et à la diffusion de documents scientifiques de niveau recherche, publiés ou non, émanant des établissements d'enseignement et de recherche français ou étrangers, des laboratoires publics ou privés. 


\title{
Valorization of industrial wastes from French maritime pine bark by solvent free microwave extraction of volatiles
}

\author{
Hamid Mellouk a, Alice Meullemiestre ${ }^{\text {b, c }}$, Zoulikha Maache-Rezzoug ${ }^{\mathrm{c}}$, Bouchra Bejjani a , \\ Adil Dani ${ }^{a}$, Sid-Ahmed Rezzoug ${ }^{\text {c, * }}$ \\ ${ }^{a}$ LGPE, FSTM, University of Hassan II, Mohammedia, Morocco \\ ${ }^{\mathrm{b}}$ Université d'Avignon et des Pays de Vaucluse, INRA, UMR408, Sécurité et Qualité des Produits d'Origine Végétale, F-84000 Avignon, France \\ ${ }^{\mathrm{c}}$ LaSIE, UMR CNRS 7356, Université de La Rochelle - Pôles Sciences et Technologie, Bâtiment Marie Curie, Avenue Michel Crépeau, 17042 La Rochelle, France
}

Keywords:

Solvent free microwave extraction

Maritime pine bark

Total phenolic compounds

Antioxidant activity

Hydrodistillation

\section{A B S T R A C T}

Solvent Free Microwave Extraction (SFME) of oil from French maritime pine bark waste and its antioxidant activity were investigated and compared to classical hydrodistillation (HD) method (Clevenger apparatus). A central composite design combined with response surface methodology was applied to evaluate the simultaneous influences of irradiation power and irradiation time. A maximal extraction yield of 3.48\% (g/100 g dry bark) was achieved under optimal extraction time of $92.4 \mathrm{~min}$ and an irradiation power of $803.5 \mathrm{~W}$ compared $2.2 \%$ obtained for the conventional method (HD). Gas chromatography coupled to mass spectrometry (GC-MS) analysis showed that SFME extract is richer in oxygenated compounds $(\sim 40 \%)$ compared to HD extract with $26 \%$. The results also showed that the two independent variables had a statistical significant effect on the considered responses namely oil yield, total phenolic compounds (TPC) and antioxidant activity assessed by 2,2-diphenyl-1-picrylhdrazyl (DPPH). Under optimized conditions, the amount of TPC was $139.15 \mathrm{mg}$ GAE/g extract largely higher than that obtained for HD extraction (14.28 $15 \mathrm{mg}$ GAE/g extract) suggesting that SFME represents an interesting alternative technology for production of recoverable oil from waste of French Maritime pine bark. The percentage inhibition was also higher for SFME extraction technique (71.91\%) than for HD (56.51\%) indicating a higher antioxidant activity.

\section{Introduction}

The lignocellulosic waste materials represent an interesting source of chemicals. Their abundant and renewable origin as well as the qualities found in their components converts them in a promising alternative resource. Maritime pine (Pinus pinaster) is a conifer native to South-Western Europe and North-Western Africa, with major forests development on Atlantic coast of southern France, Spain and Portugal (Seabra et al., 2012). Extracts isolated from plants such as pines are used as fragrances in cosmetics, flavouring additives of foods and beverages, and scenting agents in a variety of household products including detergents, soaps or insect repellent. They are also used as intermediate in the synthesis of perfume chemicals and for unconventional medicinal purposes as well as in aromatherapy (Maimoonaa et al., 2011). In this field, the traditional synthetic antioxidants food additives such as butylated

\footnotetext{
* Corresponding author. Tel.: +33 546458615; fax: +33 546458241 E-mail address: sarezzou@univ-lr.fr (S.-A. Rezzoug).
}

hydroxyanisole (BHA) and butylated hydroxytoluene (BHT) showed some negative side effects on health (Sarikurkcu et al., 2007) due to their instability and high volatility (Li et al., 2008). Therefore, increasing interest in natural antioxidant present in the diet has developed among consumers and the scientist community an interest to replace synthetic antioxidants (Inan et al., 2012). A lot of research work have been reported about antioxidant properties of different plant extracts (Ozkan and Erdogan, 2011; Zhang et al., 2014), and confirmed that the phenolic components in isolated oils were the main source of antioxidant activity (Karabegović et al., 2014).

The technologies used to extract essential oils from plant materials are enormous and usually have some disadvantages as high temperature, long processing time as in the conventional hydrodistillation or the solvent extraction in which a loss of volatile compounds occurs during solvent removal (Rodríguez-Rojo et al., 2012). For a few years, the change in attitude has evolved increasingly to a "green" tendency and there has been an increasing demand for new cleaner techniques for essential oil extraction. These new green processes will be more environmentally friendly 
with a shorter extraction times, lesser consumption of organic solvent and energy, and minor waste and $\mathrm{CO}_{2}$ emissions, while maintaining a high quality of extract. Some intensified extraction methods were investigated including microwave (Gholivand et al., 2013; Fernández-Agulló et al., 2015) supercritical fluids (Herzi et al., 2013; Stashenko et al., 2013), D.I.C-assisted extraction (Mellouk et al., 2013; Rezzoug, 2009) or ultrasound assisted extraction (Meullemiestre et al., 2014; González-Centeno et al., 2015; Ghitescu et al., 2015). Currently, application of microwave technology-based methods such as solvent free microwave extraction (SFME) becomes highly desirable as a valid alternative to conventional methods and this extraction technology was the subject of several studies (Chen et al., 2011; Ma et al., 2012; Ranic et al., 2014). To the best of our knowledge, no work has been published on the antioxidant activity of oil extracted from industrial wood wastes by solvent free microwave extraction. In the present work, isolation of waste extracts from French maritime pin bark issued from timber industry was optimized using SFME method. A central composite design (CCD) has been developed to assess the effect of two independent variables namely microwave irradiation power and irradiation time on extraction yield, on the amount of total phenolic compounds and on the percentage inhibition of DPPH radical (2,2diphenyl-1-picrylhydrazyl). The results were compared with those of hydrodistillation (HD) as a conventional extraction method.

\section{Materials and methods}

\subsection{Plant material and chemicals}

French maritime pine bark (P. pinaster) provided by Archimbaud Company (Secondigné/Belle, France) in March 2014. The chips were coarsely crushed and dried for $24 \mathrm{~h}$ at $25^{\circ} \mathrm{C}$. Moisture content was measured using a halogen Moisture Analyzer (Ohaus - MB 35) at $105{ }^{\circ} \mathrm{C}$ and corresponded to $12.3 \% \mathrm{db}$ (dry basis). After storage in a refrigerated room at $4{ }^{\circ} \mathrm{C}$, fresh material was employed in all experiments after adding water to reach about $50 \%$ moisture content (for SFME). 2,2-Diphenyl-1-picrylhydrazyl hydrate (DPPH), anhydrous sodium carbonate, gallic acid, Folin-Ciocalteu's phenol reagent were purchased from Sigma-Aldrich and Methanol, $\mathrm{Na}_{2} \mathrm{CO}_{3}$ were from Fisher scientific.

\subsection{Protocol}

In the present study, the experimental design was achieved as illustrated in Fig. 1. Extraction of volatile molecules was performed by HD and SFME methods. Each HD operation was performed three times in order to test reproducible. SFME treatments were analysed and optimised through statistical study. For HD and for SFME in optimised conditions, the antioxidant activity and total phenolic compounds were evaluated.

\subsection{SFME apparatus and procedure}

Solvent-free microwave extraction has been performed on a Milestone NEOS microwave station (NEOS microwave laboratory oven) (Fig. 2). It is a multimode microwave reactor $2.45 \mathrm{GHz}$ with a maximum delivered power of $1000 \mathrm{~W}$ variable in $10 \mathrm{~W}$ increments. Temperature was monitored by an external infrared sensor. In a typical procedure $100 \mathrm{~g}$ of moistened bark chips were subjected to microwave irradiations in oven cavity, initially at ambient temperature, during a fixed processing time. The microwave heating of the water contained inside the raw material allows releasing molecules constituting isolated oil. This oil was then driven by the generated vapour. A cooling system outside the microwave cavity permitted to condensate the distillate

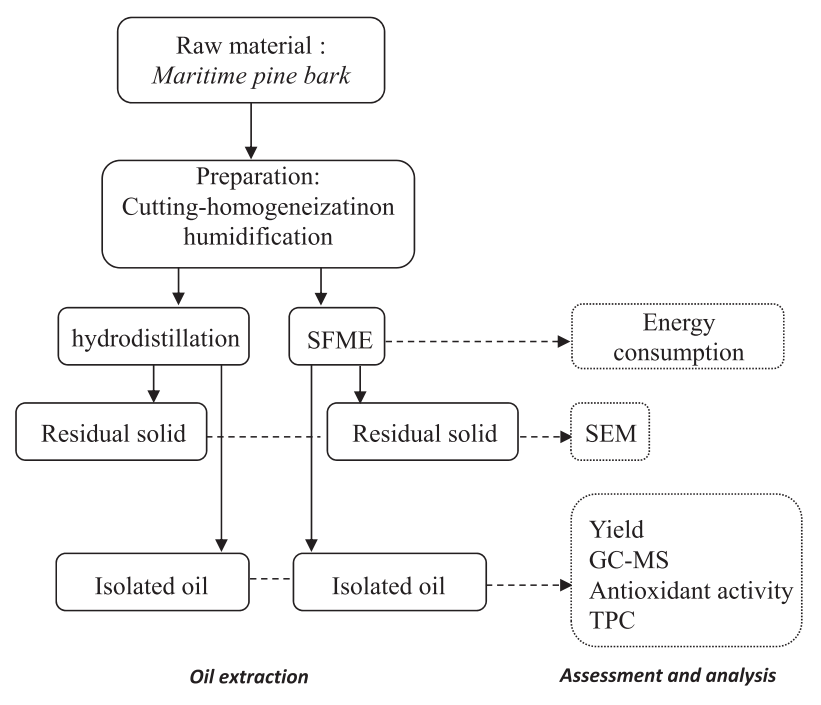

Fig. 1. Protocol of extraction and analysis of oil from maritime pine bark waste.

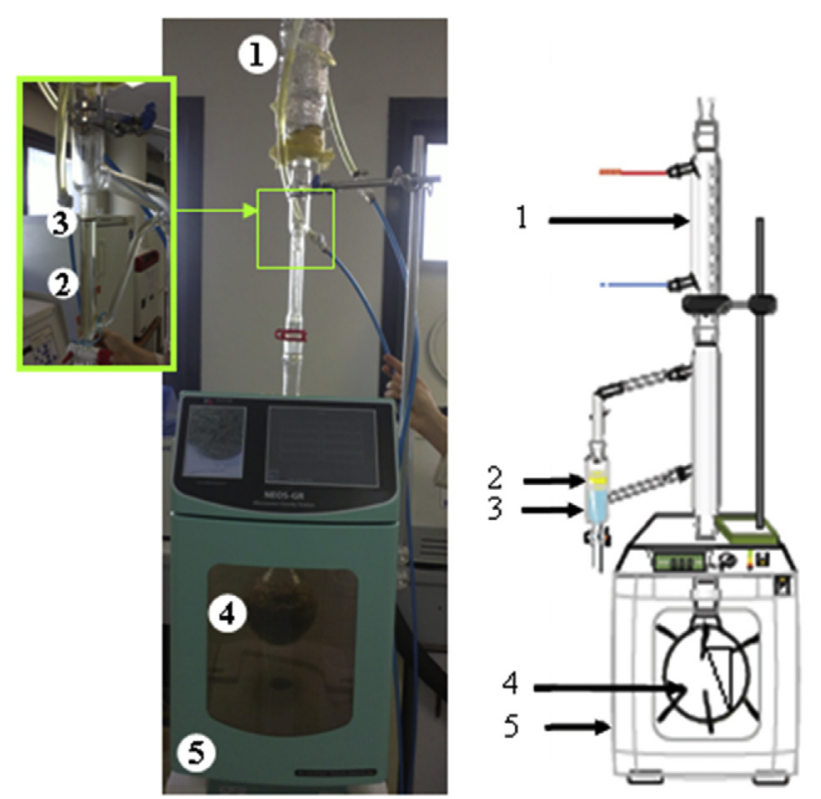

Fig. 2. Solvent free microwave extraction apparatus (SFME): (1) refrigerant system; (2) aqueous fraction; (3) oil fraction; (4) maritime pine bark; (5) microwave oven.

continuously $\left(5{ }^{\circ} \mathrm{C}\right)$. Condensed water was refluxed to the extraction vessel in order to provide uniform conditions of temperature and humidity. Isolated oil was dried with anhydrous sodium sulphate and stored at $4{ }^{\circ} \mathrm{C}$ in the dark until used. Extraction yield was calculated according to eq. 1

Extraction yield $(\%)=\left(\frac{\text { mass of extracted essential oil }}{\text { mass of dry material }}\right) \times 100$

\subsection{Hydrodistillation apparatus and procedure}

Conventional hydrodistillation apparatus (Clevenger-type apparatus) according to the European Pharmacopeia (2012) was employed. A quantity of $100 \mathrm{~g}$ of maritime pine bark for $1 \mathrm{~L}$ of 
distilled water was used to perform the hydrodistillation during $300 \mathrm{~min}$ from the first drop of distillate fell until the raw material has been completely exhausted. Isolated oil was collected, dried under anhydrous sodium sulphate, and stored at $4{ }^{\circ} \mathrm{C}$ for further analysis. Each extraction was performed at least three times, and a standard deviation was calculated. The extraction yield was calculated according to eq. (1).

\subsection{Experimental design}

The relationships between response functions and process variables have been established by using a central composite design (CCD) as well as the optimal conditions of the developed process. The independent variables were coded according to eq. (2):

$x_{i}=\frac{\mathrm{X}_{\mathrm{i}}-\mathrm{X}_{\mathrm{i} 0}}{\Delta \mathrm{X}_{\mathrm{i}}} \quad \mathrm{i}=1,2$

where $x_{i}$ and $X_{i}$ are respectively the dimensionless and the actual values of the independent variable $i, X_{i 0}$ is the actual value of the independent variable $i$ at the central point, and $\Delta \mathrm{X}_{\mathrm{i}}$ is the step change of $\mathrm{X}_{\mathrm{i}}$ corresponding to a unit variation of the dimensionless value. Irradiation power $\left(x_{1}\right)$ and processing time $\left(x_{2}\right)$ were chosen as independent variables. The selected responses were the total yield of maritime pine bark oil (\%), the total phenolic compounds (mg GAE/g extract) and the antioxidant activity expressed by the percentage inhibition of DPPH radical. For the two variables, the design yielded 14 experiments with four $\left(2^{2}\right)$ factorial points, four axial points $(-\alpha$ and $+\alpha)$ to form a central composite design and six center points for replications and estimation of the experimental error and to prove the suitability of the model. Both coded and actual values of the independent variables and their ranges of variations are listed in Table 1.

$\mathrm{Y}=\beta_{0}+\sum_{i=1}^{n} \beta_{i} x_{i}+\sum_{i=1}^{n} \beta_{i i} x_{i}^{2}+\sum_{i \neq j} \beta_{i j} x_{i} x_{j}$

The responses $Y$ are related to the coded independent variables $x_{i}$ and $x_{j}$ according to the second order polynomial expressed in eq. (3), with $\beta_{0}$ the interception coefficient, $\beta_{i}$ the linear terms, $\beta_{i i}$ the quadratic terms, $\beta_{i j}$ the interaction terms. Fisher test for analysis of variance (ANOVA) performed on experimental data permitted to estimate the statistical significance of the proposed models. Response surfaces as represented by Fig. 3 were drawn by using the analysis design procedure of Statgraphics Plus for Windows software (Centurion version).

\subsection{GC-MS identification}

The volatile compounds were analyzed by gas chromatography coupled to mass spectrometry (GC-MS). Analyses were performed on a GC/MS Varian 3900 chromatograph coupled to a Saturn 2100T mass spectrometer using fused-silica-capillary column. The nonpolar column was Elite 5MS $(30 \mathrm{~m} \times 0.25 \mathrm{~mm} \times 0.25 \mu \mathrm{m}$ film

Table 1

Coded levels for independent variables used in developing experimental data.

\begin{tabular}{lrrrrr}
\hline & \multicolumn{1}{l}{ Coded level } \\
\cline { 2 - 6 } & \multicolumn{1}{c}{$-\alpha$} & \multicolumn{1}{c}{0} & \multicolumn{1}{c}{0} & \multicolumn{1}{c}{1} & \multicolumn{1}{c}{$+\alpha$} \\
\hline Irradiation power $(\mathrm{W})$ & 96.4 & 200 & 450 & 700 & 803.6 \\
Processing time (min) & 7.6 & 20 & 50 & 80 & 92.4 \\
\hline
\end{tabular}

$\alpha$ (axial distance $)=\sqrt[4]{\mathrm{N}}, \mathrm{N}$ is the number of experiments of orthogonal design, i.e. of the factorial design. In this case $\alpha=1.41$. The two variables were studied in five levels.
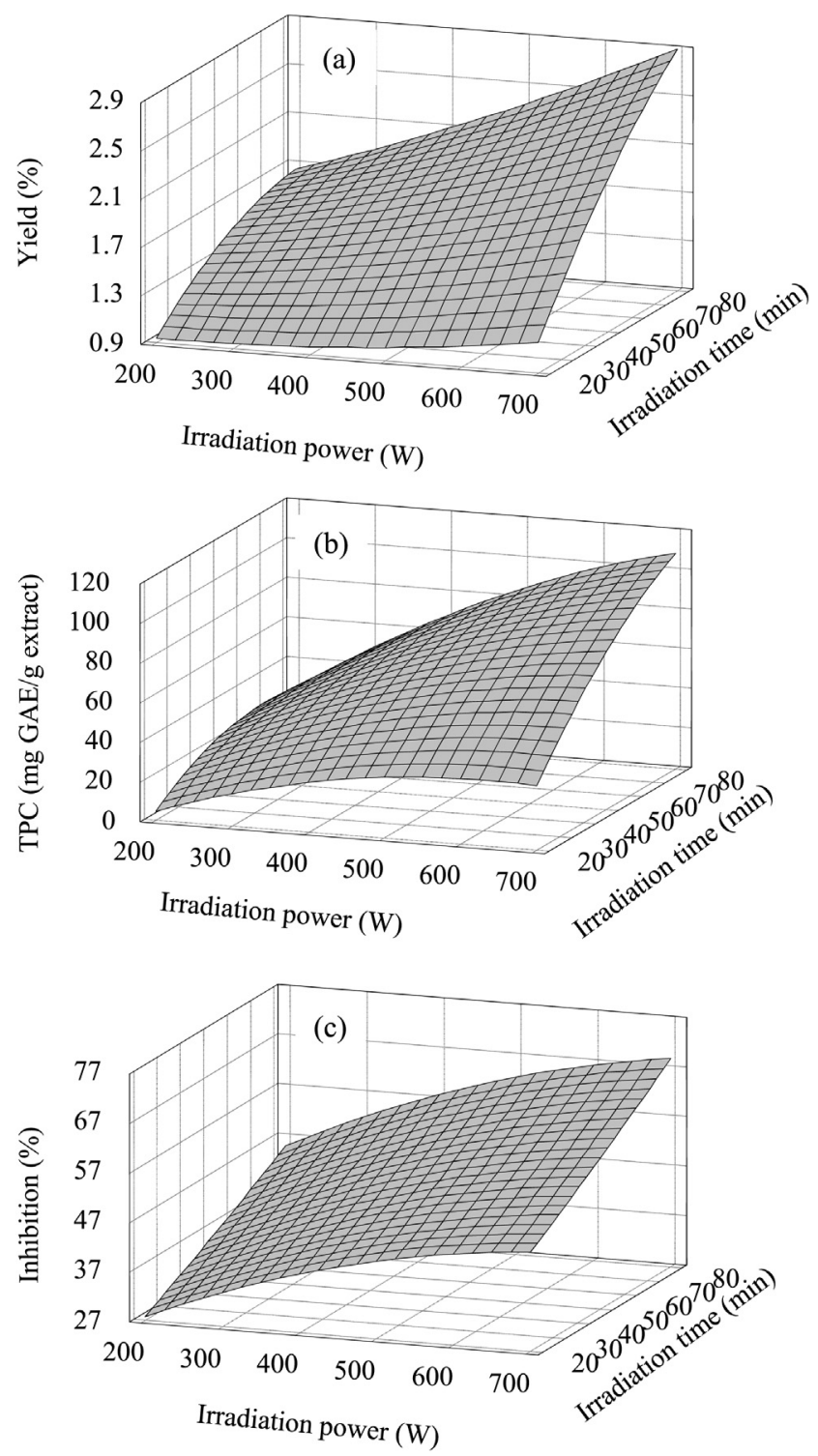

Fig. 3. Responses surfaces showing the simultaneous effect of irradiation power and irradiation time on the considered responses.

thickness). GC-MS spectra were obtained using the following conditions: He (helium) as carrier gas at flow rate of $1 \mathrm{~mL} / \mathrm{min}$; split mode1:20; $1 \mu \mathrm{L}$ as injected volume; $250{ }^{\circ} \mathrm{C}$ as injection temperature. The oven temperature programme was $60{ }^{\circ} \mathrm{C}$ for $5 \mathrm{~min}$ increasing at $2{ }^{\circ} \mathrm{C} / \mathrm{min}$ towards $250{ }^{\circ} \mathrm{C}$ and held at $250{ }^{\circ} \mathrm{C}$ during $10 \mathrm{~min}$. The ionization mode used was electronic impact at $70 \mathrm{eV}$. Most constituents were identified by comparison of their GC linear retention indices (RI), determined with reference to a homologous series of C5-C32 n-alkanes. The identification was confirmed by comparison of the mass spectral with those stored in the MS database (National Institute of Standards and Technology NIST08 and Wiley libraries) and also by comparison with mass spectra from literature data (Adams, 2007). The percentage composition was calculated from the summation of peak areas of the total oil.

\subsection{Assay for total phenolics}

Total phenols in maritime pine bark extracts was determined using spectrophotometric Folin-Ciocalteu method according to the 
Version définitive du manuscrit publiée dans / Final version of the manuscript published in :

Journal of Cleaner Production (2016), Vol. 112, p. 4398-4405, DOI: 10.1016/j.jclepro.2015.06.129

Journal homepage : www.elsevier.com/locate/jclepro

literature methods (Orhan et al., 2013; Kim et al., 2010) with some modifications, using gallic acid as standard. Extract solution $(0.5 \mathrm{~mL})$ of diluted samples were added into test tubes followed by $2.5 \mathrm{~mL}$ of Folin-Ciocalteu reagent $(20 \%, \mathrm{v} / \mathrm{v})$. After $5 \mathrm{~min}, 2 \mathrm{~mL}$ of a solution of $7 \% \mathrm{Na}_{2} \mathrm{CO}_{3}$ was added. All test tubes with the mixture were caped and shaken for $10 \mathrm{~s}$ and put on to incubation in a water bath at $45{ }^{\circ} \mathrm{C}$ for $5 \mathrm{~min}$. Absorbance was measured after $30 \mathrm{~min}$ at 765 nm (Helios Omega UV/VIS Thermo Scientific Merck and Co. Spectrophotometer) against blank sample. The same procedure was repeated for all standard gallic acid solutions $(2-200 \mu \mathrm{g} / \mathrm{mL})$ and a standard curve was obtained with Eq. (4) $\left(R^{2}=0.99\right)$ :

Absorbance $=0.0109 \times$ Gallic $\operatorname{acid}(\mu \mathrm{g} / \mathrm{mL})+0.037$

The results were expressed as milligrams of Gallic acid equivalents (GAE) per g extract. The analyses were performed in triplicate and standard deviation was calculated.

\subsection{DPPH assay for evaluation of antioxidant activity}

The chemical compound 2,2-diphenyl-1-picrylhydrazyl (DPPH) is one of the first free radicals used for studying the structure-activity relationship antioxidant phenolic compounds (Brand-Williams et al., 1995). In this method, the antioxidant activity of oil extract is evaluated in term of the capacity to scavenging free radicals of DPPH formed, according to a method described by Lue et al. (2010). A solution of $4 \mathrm{mg}$ of the radical DPPH dissolved in $100 \mathrm{~mL}$ of methanol was prepared. Then $3 \mathrm{~mL}$ of this solution was reacted with $1 \mathrm{~mL}$ of oil diluted bark extract (dissolved in methanol). The mixture was incubated in dark for $30 \mathrm{~min}$ at room temperature. The absorbance was measured at $517 \mathrm{~nm}$ with Helios Omega UV/VIS Thermo Scientific Merck and Co. Spectrophotometer. The percentage inhibition activity was calculated by eq. (5):

$\mathrm{I} \%=\left(\frac{\mathrm{A}_{0}-\mathrm{A}_{t}}{\mathrm{~A}_{0}}\right) \times 100$

where $A_{0}$ is the absorbance of the control sample (without isolated oil) and $A_{t}$ the absorbance of the extract with DPPH at $30 \mathrm{~min}$. All analyses were run in triplicates and averaged.

\subsection{Scanning electron microscopy}

Microstructures were observed using an environmental SEM FEI/Philips Quanta 200 FEG (Field Effect Gun). Samples were observed under 1.00 mbar of water vapour pressure without any metallic coverage. The accelerating voltage used is $20 \mathrm{kV}$ and the secondary electrons (SE) images were obtained with a Large-Field Detector (LFD).

\section{Results and discussion}

\subsection{Regression coefficients and fitting the models}

The complete design matrix together with the values of experimental yield, the total phenolic compounds and percentage inhibition are given in Table 2. A regression analysis was carried out to fit mathematical models to the experimental data aiming at an optimal region for the studied responses. The predicted models can be described by Table 3 in term of coded values. The significance of each coefficient was determined using Fisher test (F-value) and the probability $\mathrm{p}$ ( $p$-value) in Table 4 , which displays the variance analysis of the system (ANOVA). Corresponding variables would be more significant if absolute $F$-value becomes greater and $p$-value
Table 2

Experimental data and obtained responses with the different combinations of irradiation power $\left(x_{1}\right)$ and irradiation time $\left(x_{2}\right)$ used in the randomized central composite design.

\begin{tabular}{|c|c|c|c|c|c|}
\hline \multirow[t]{2}{*}{ Run } & \multicolumn{2}{|c|}{$\begin{array}{l}\text { Coded variable } \\
\text { level }\end{array}$} & \multicolumn{3}{|c|}{ Experimental responses data } \\
\hline & $x_{1}$ & $x_{2}$ & Yield $^{\mathrm{a}}$ & $\mathrm{TPC}^{\mathrm{b}}$ & Inhibition $^{c}$ \\
\hline 1 & -1 & -1 & 1.02 & 8.35 & 31.82 \\
\hline 2 & 1 & -1 & 0.92 & 23.45 & 46.29 \\
\hline 3 & -1 & 1 & 1.72 & 20.31 & 40.75 \\
\hline 4 & 1 & 1 & 2.65 & 90.77 & 59.99 \\
\hline 5 & $-\alpha$ & 0 & 1.23 & 1.19 & 27.34 \\
\hline 6 & $+\alpha$ & 0 & 2.67 & 60.20 & 64.31 \\
\hline 7 & 0 & $-\alpha$ & 0.68 & 9.95 & 33.95 \\
\hline 8 & 0 & $+\alpha$ & 2.41 & 91.87 & 73.37 \\
\hline 9 & 0 & 0 & 1.73 & 69.29 & 69.79 \\
\hline 10 & 0 & 0 & 1.66 & 51.81 & 55.96 \\
\hline 11 & 0 & 0 & 1.47 & 46.52 & 47.90 \\
\hline 12 & 0 & 0 & 1.79 & 42.37 & 43.62 \\
\hline 13 & 0 & 0 & 1.88 & 50.52 & 55.19 \\
\hline 14 & 0 & 0 & 1.86 & 49.61 & 51.36 \\
\hline \multicolumn{3}{|c|}{$\begin{array}{l}\text { Mean absolute error for } \\
\text { replications }\end{array}$} & 0.13 & 9.2 & 8.9 \\
\hline
\end{tabular}

a $\mathrm{g} / 100 \mathrm{~g}(\mathrm{~d} . \mathrm{m})$ or \%.
b $\mathrm{mg} \mathrm{GAE} / \mathrm{g}$ extract.

c $\%$.

Table 3

Regression coefficients of the second-order polynomial equations.

\begin{tabular}{|c|c|c|c|}
\hline \multirow[t]{2}{*}{ Regression coefficients } & \multicolumn{3}{|c|}{ Response variables } \\
\hline & Yield (\%) & TPC (mg GAE/g extract & Inhibition (\%) \\
\hline$\beta_{0}$ & 1.71 & 61.76 & 50.33 \\
\hline$\beta_{1}$ & 0.73 & 55.45 & 21.50 \\
\hline$\beta_{2}$ & 1.22 & 48.78 & 19.59 \\
\hline$\beta_{12}$ & 0.51 & 27.67 & 2.38 \\
\hline$\beta_{11}$ & 0.16 & -19.60 & -7.02 \\
\hline$\beta_{22}$ & -0.25 & -18.06 & 0.81 \\
\hline
\end{tabular}

of respectively irradiation power and irradiation time.

becomes smaller. For the yield of maritime pine bark isolated oil, it can be seen that the linear terms are strongly significant $(p<0.05)$. The interaction between irradiation power and processing time was also significant with a confidence level of approximately $97 \%$. For total phenolic compounds, unlike the yield of extracted oil, all effects were found statistically significant with predominance for the linear effects of irradiation power and processing time. The significance of the two quadratic effects suggests a degradation of the phenolic compounds.

According to Abdelhadi et al. (2014), this degradation concerns the oxygenated compounds of the oil during a prolonged processing time or for high microwave intensity. The interaction between irradiation power and processing time was also statistically significant indicating an antagonistic effect of the two factors. Concerning the inhibition of DPPH radical, the linear effects of irradiation power and processing time were significant. In general way, the results suggest that changing in irradiation power and irradiation time had a highly significant effect on the yield of isolated oil, on its composition in phenolic compounds as well as on its capacity to scavenging DPPH radical. The quality of the models developed was evaluated based on the correlation coefficient $\mathrm{R}^{2}$ and on the lack-of fit value. From ANOVA (Table 4), it can be seen that $\mathrm{R}^{2}$ were systematically close to $90 \%$ and $p$-value of lack-of-fit systematically higher than 0.05 (non-significant) suggesting that 
Version définitive du manuscrit publiée dans / Final version of the manuscript published in :

Journal of Cleaner Production (2016), Vol. 112, p. 4398-4405, DOI: 10.1016/j.jclepro.2015.06.129

Journal homepage : www.elsevier.com/locate/jclepro

Table 4

Analysis of variance showing the effect of the three independent variables as linear, quadratic and cross products terms on the studied responses.

\begin{tabular}{lllcrl}
\hline & Source & DF & Sum of square & F-ratio & P-value \\
\hline Yield (\%) & $x_{1}$ & 1 & 1.06 & 45.26 & 0.0025 \\
& $x_{2}$ & 1 & 3.00 & 127.99 & 0.0003 \\
& $x_{1} \mathrm{x}_{2}$ & 1 & 0.26 & 11.26 & 0.0284 \\
& $x_{1}^{2}$ & 1 & 0.03 & 1.78 & 0.2526 \\
& $x_{2}^{2}$ & 1 & 0.14 & 4.50 & 0.1011 \\
& Lack-of-fit & 3 & 0.22 & 3.18 & 0.1462 \\
& Pure error & 4 & 0.094 & & \\
TPC & $\mathrm{R}^{2}$ & 0.93 & & & \\
& $x_{1}$ & 1 & 6151.08 & 121.95 & 0.0004 \\
& $x_{2}$ & 1 & 4759.21 & 94.36 & 0.0006 \\
& $x_{1} x_{2}$ & 1 & 766.016 & 15.19 & 0.0176 \\
& $x_{1}^{2}$ & 1 & 668.07 & 13.25 & 0.0220 \\
& $x_{2}^{2}$ & 1 & 567.31 & 11.25 & 0.0285 \\
& Lack-of-fit & 3 & 904.48 & 5.98 & 0.0584 \\
& Pure error & 4 & 201.76 & & \\
& $\mathrm{R}^{2}$ & 0.92 & & & \\
& $x_{1}$ & 1 & 924.78 & 34.23 & 0.0043 \\
& $x_{2}$ & 1 & 768.08 & 28.43 & 0.0060 \\
& $x_{1} x_{2}$ & 1 & 5.69 & 0.21 & 0.6701 \\
& $x_{1}^{2}$ & 1 & 85.82 & 3.18 & 0.1493 \\
& $x_{2}^{2}$ & 1 & 1.14 & 0.04 & 0.8473 \\
& Lack-of-fit & 3 & 230.85 & 2.85 & 0.1690 \\
& Pure error & 4 & 108.07 & & \\
& $\mathrm{R}^{2}$ & 0.84 & & & \\
\hline
\end{tabular}

the predicted models reasonably represent the observed values. Thus the responses were sufficiently explained by the models.

\subsection{Response surfaces analysis}

Three-dimensional profiles of multiple non-linear regression models (Fig. 3) were used to illustrate the linear and quadratic effects of the two key variables as well as the interaction effects between irradiation power and irradiation time on extraction yield, total phenolic compounds and on the percentage inhibition obtained from DPPH test. In each plot, the third variable is fixed at its central value ("0"). The most influential effects on the yield of isolated oil are the linear terms of irradiation power $\left(x_{1}\right)$ and irradiation time $\left(x_{2}\right)$. Fig. 3a clearly shows that the yield increased linearly as irradiation power and irradiation time increased. This increasing was also pointed out by Dai and Mumper (2010) and AlFarsi and Lee (2008) for which a high temperature favoured the extraction process by enhancing the solubility of phenolic compounds and the mass transfer rate (Dai and Mumper, 2010) and by weakening the plant tissues. The interaction between irradiation power and processing time is also visible on Fig. 3a; when irradiation power increased from its low level $(200 \mathrm{~W})$ to its high level $(700 \mathrm{~W})$, a weak variation in the yield was observed, from $0.94 \%$ to $1.15 \%$, for a processing time fixed at $20 \mathrm{~min}$. Conversely, a strong evolution was observed, from $1.64 \%$ to $2.89 \%$ for a processing time fixed at $40 \mathrm{~min}$. For the total phenolic compounds, the quadratic effect of irradiation power and in a lesser extent that associated to the processing time are visible on Fig. 3b on which a maximum of total phenolic compounds seems to be reached for the highest values of the two processing variables. On this figure, it can be also noticed a strong interaction; when irradiation power increase from $200 \mathrm{~W}$ to $700 \mathrm{~W}$, TPC increased from 4.11 to $31.40 \mathrm{mg}$ GAE eq/g extract with a maximum of $33.6 \mathrm{mg}$ GAE eq/g extract for a processing time fixed at $20 \mathrm{~min}$ while for a same variation, the phenolic compounds increased continuously from 25.31 to $108.43 \mathrm{mg}$ GAE eq/g extract for a processing time fixed at $40 \mathrm{~min}$. Concerning the radical-scavenging properties, the linear effects of irradiation power and irradiation time are clearly visible as testified by a flat growing surface (Fig. 3c).

\subsection{SFME versus $H D$}

\subsubsection{Yield, total phenolics and antioxidant activity}

For isolated oil yield the optimal conditions selected by the software were the highest values of irradiation power $(803.6 \mathrm{~W})$ and irradiation time (92.4 min). Under these conditions, the software indicates an optimum yield of $3.51 \%$ while the experimental yield was about 3.34\%. This difference can be due to a loss of oil on the flask test walls. From kinetic point of view (Fig. 4), HD extraction results were compared with the results obtained for run 7,8 and means of the four repetitions (runs from 10 to 13). The maximum HD extraction of $2.2 \%$ was reached after about $180 \mathrm{~min}$ while for SFME, a higher yield of $2.41 \%$ was obtained in a lesser time (92.4 $\mathrm{min}$ ) for an intermediate irradiation power $(450 \mathrm{~W})$. It should be noted that in the optimal conditions of SFME extraction $(803 \mathrm{~W}$; $92.4 \mathrm{~min}$ ) the yield was largely enhanced (by about 53\%) compared to hydrodistillation method. In both HD and SFME extraction processes, the kinetics was reported to take place in two distinct phases (Pavićević et al., 2015). The first one is represented by an increasing line until the temperature reaches $100{ }^{\circ} \mathrm{C}$ and thus achieves the distillation of the first oil droplet. In the second part, the extraction temperature is approximately equal to water boiling temperature at atmospheric pressure. However, the most important differences were observed between the both extraction methods is the ability of SFME process to quickly raise the temperature of the sample to $100^{\circ} \mathrm{C}$. This rapid increasing of extraction temperature gives to acceleration of extraction rates under microwaves and could be due to a synergetic combination of heat and mass transfer phenomena. For HD, mass transfer occurs from inside to outside whilst heat transfer occurs from outside to inside. For microwave extraction, the two transport phenomena act in the same direction, from inside to outside, which facilitates oil diffusion (Farhat et al., 2011; Desai and Parikh, 2015). Fig. 4 seems to confirm this argumentation although the second phase is not really reached for SFME. The Folin-Ciocalteu method allowed a good discrimination between the SFME and HD extracts (Table 5). The results clearly shown that the application of microwaves leads to recover phenolic compounds with a higher concentration in comparison with methods based on hydrodistillation, respectively 139.15 and $14.28 \mathrm{mg} \mathrm{GAE} / \mathrm{g}$ extract for SFME and HD. Thus SFME appears to be is an efficient technology to save the structure of phenolic groups

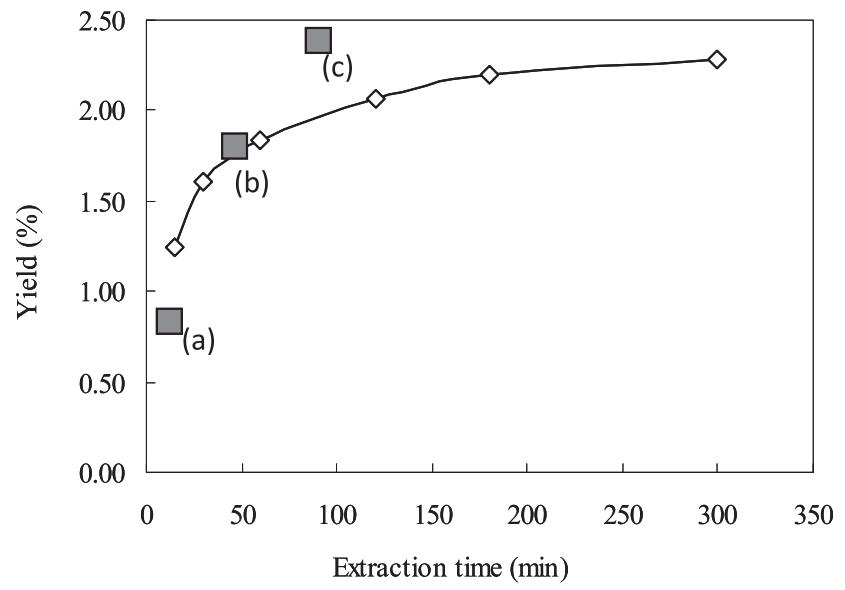

Fig. 4. Comparison of extraction kinetics of HD $(\diamond)$ and SFME ( $\square$ ). (a): run 7, (b): means of runs $10-13$ and (c) run 8 
Version définitive du manuscrit publiée dans / Final version of the manuscript published in :

Journal of Cleaner Production (2016), Vol. 112, p. 4398-4405, DOI: 10.1016/j.jclepro.2015.06.129

Journal homepage : www.elsevier.com/locate/jclepro

Table 5

Comparison of extraction yield, TPC amount and the percentage of DPPH inhibition for SFME (92.4 min, 803.5 W) and HD (180 min).

\begin{tabular}{llll}
\hline & Yield $(\mathrm{g} / 100 \mathrm{~g}$ d.b) & TPC $(\mathrm{mg}$ GAE $/ \mathrm{g}$ extract $)$ & Inhibition (\%) \\
\hline SFME & 3.34 & 139.15 & 71.9 \\
HD & 2.20 & 14.28 & 56.5 \\
BHT & & & 93.2 \\
\hline
\end{tabular}

and avoid their contribution in side reactions. On the other hand, the two extract exhibited concentration-dependant DPPH radical scavenging activity. For a fixed value of extract concentration indicated in section 2.8, the reducing capacity of SFME isolated extract quantified as a percentage inhibition was higher than that of HD, respectively $71.9 \%$ and $56.5 \%$. The findings above show the presence of natural antioxidant phenolic compounds in pine bark waste with a good performance since the SFME antioxidant activity can be favourably compared with that of BHT (butylated hydroxytoluene) (93.2\%) known as a very efficient synthetic antioxidant agent and widely used in food technology. The good antioxidant activity of SFME extracts may be attributed to the presence of a higher quantity of oxygenated monoterpenes and in lesser extent monoterpene hydrocarbons> (Park and Lee, 2011).

\subsubsection{Chemical composition}

For both HD and SFME isolated oils, about 55 components were respectively identified among which monoterpene and sesquiterpene hydrocarbons as well as oxygenated monoterpenes and sesquiterpenes. From Table 6, it can be seen that isolated oils obtained by SFME and HD have equivalent percentages in non-oxygenated compounds, respectively $37.6 \%$ and $32.1 \%$. Conversely for SFME the predominant group is that of oxygenated compounds (40.8\%) compared to HD (26.8\%). Orio et al. (2012) have linked this phenomenon to microwave energy effect which differs for oxygenated and non-oxygenated groups of compounds. For the more polar compounds (oxygenated compounds), the more easily the microwaves irradiations are absorbed, the better the interaction between electromagnetic wave and matter is established and more polar aromatic components are obtained, conversely to sesquiterpenes and monoterpenes hydrocarbons. Electromagnetic interactions are also cited as possible cause to presence of more oxygenated compounds in SFME extracts: organic compounds that have a high dipolar moment as many oxygenated compounds interact more vigorously with microwaves and can be extracted more easily. It should be noted that the oxygenated compounds are most valuable in plant isolated oils; they are characteristic of a strong odour and are known to play a key role in the antioxidant activity. Among the oxygenated compounds, $\alpha$-terpineol seems to be predominant in SFME extracts and probably have also a part in antioxidant activity as it was remarked by Li et al. (2012).

\subsection{Microstructural changes after extraction}

Pine bark samples were examined by SEM for an evaluation of the microstructural alteration induced by SFME and HD extractions compared to untreated sample. As shown in Fig. 5A, the external surface of untreated sample was smooth and contains many folds. After extraction by HD (Fig. 5B) some ruptures and perforations appeared on the leaf surface and the folds were still present while after extraction by SFME (Fig. 5C), perforations and creation of canals was clearly observed and the surface appeared completely disrupted indicating that the strain induced by a rapid rise in temperature in SFME extraction and subsequent change in the surface tension of the glandular wall, causing it to crumble or rupture more readily.
Table 6

Chemical composition of maritime pine sawdust waste oils obtained by GC-MS.

\begin{tabular}{|c|c|c|c|}
\hline Compounds & Rt & SFME & HD \\
\hline$\alpha$-Pinene & 11.51 & 2.35 & 2.32 \\
\hline 3-Carene & 11.52 & 2.23 & 1.87 \\
\hline$\alpha$-Thujene & 11.57 & 0.33 & 0.21 \\
\hline Cis-ocymene & 11.58 & 0.38 & 0.12 \\
\hline Trans-ocymene & 11.6 & 0.57 & 0.45 \\
\hline Benzylalcohol & 11.84 & 1.34 & 1.25 \\
\hline Tricyclo[2.2.1.0(2,6)]heptan & 11.88 & 0.93 & 0.87 \\
\hline Tricyclo[3.2.1.0(2,4)]octane & 11.92 & 0.95 & 1.26 \\
\hline Bicyclo[3.1.1]hept-2-ene-2-e & 11.98 & 0.42 & 0.12 \\
\hline 1,3,6-Octatriene, 3,7-dimeth & 12.04 & 1.09 & 0.85 \\
\hline Cyclofenchene & 12.1 & 4.36 & 3.76 \\
\hline Camphene & 12.92 & 0.31 & 0.49 \\
\hline$\beta$-Pinene & 13.97 & 5.46 & 5.17 \\
\hline$\beta$-Cymene & 16.85 & 0.37 & 0.26 \\
\hline Limonene & 16.97 & 2.13 & 1.93 \\
\hline Artemiseole & 19.72 & 0.2 & 0.18 \\
\hline$(+)$-4-Carene & 20.06 & 0.47 & 0.42 \\
\hline Terpinolene & 20.11 & 0.23 & 0.13 \\
\hline$\alpha$-4-Dimethylstyrene & 20.53 & 0.99 & 0.63 \\
\hline Exa-Fenchol & 22.24 & 1.03 & 0.91 \\
\hline$\alpha$-Campholenal & 22.63 & 0.23 & 0.14 \\
\hline 6-Camphenol & 22.77 & 0.26 & 0.15 \\
\hline L-trans-pinocarveol & 23.41 & 1.07 & 0.87 \\
\hline L-camphor & 23.7 & 1.12 & 0.17 \\
\hline Linalool & 24.11 & 0.32 & 0.13 \\
\hline Cis- $\beta$-terpineol & 24.29 & 0.39 & 0.46 \\
\hline Trans- $\beta$-terpineol & 24.41 & 0.13 & 0.26 \\
\hline Pinocarvone & 24.62 & 0.49 & 0.72 \\
\hline Perillaldehyde & 24.81 & 0.37 & 0.62 \\
\hline Isoborneol & 25.18 & 1.01 & 1.27 \\
\hline Borneol & 25.37 & 1.54 & 1.46 \\
\hline 4-Terpineol & 25.67 & 2.19 & 0.71 \\
\hline$\alpha$-Terpineol & 26.36 & 19.54 & 8.35 \\
\hline Valencene & 36.85 & 2.7 & 2.76 \\
\hline$\beta$-Caryophyllene & 37.40 & 7.63 & 4.92 \\
\hline$\alpha$-Humulene & 39.13 & 3.34 & 2.19 \\
\hline$\alpha$-Muurolene & 41.32 & 0.16 & 0.17 \\
\hline$\delta$-Cadinene & 42.20 & 0.61 & 1.06 \\
\hline$\alpha$-Cadinene & 42.38 & 0.24 & 0.37 \\
\hline Guaiacol & 43.79 & 0.54 & 0.44 \\
\hline Eudesmol & 44.08 & 0.99 & 0.84 \\
\hline (+)-Longicamphenylone & 44.56 & 0.16 & 0.19 \\
\hline Caryophyllenyl alcohol & 44.88 & 1.19 & 1.09 \\
\hline Caryophyllene oxide & 45.15 & 1.42 & 1.51 \\
\hline Gamma-gurjunenepoxide-(2) & 45.78 & 0.37 & 0.18 \\
\hline Longiborneol & 46.11 & 0.82 & 0.63 \\
\hline 3,7-Cycloundecadien-1-ol, 1,5,5,8-tetramethyl & 46.31 & 0.47 & 0.42 \\
\hline Cubenol & 47.24 & 0.81 & 0.75 \\
\hline Calarene epoxide & 47.59 & 0.14 & 0.18 \\
\hline Isoaromadendrene epoxide & 47.6 & 0.49 & 0.43 \\
\hline Aromadendrene oxide-(2) & 49.29 & 0.36 & 0.24 \\
\hline Biformene & 58.81 & 0.68 & 1.34 \\
\hline$\alpha$-Himachalene & 60.32 & 0.2 & 0.5 \\
\hline Verticiol & 60.93 & 0.33 & 0.77 \\
\hline Sclarene & 61.16 & 0.36 & 0.77 \\
\hline Manoyl oxide & 61.88 & 1.28 & 1.95 \\
\hline Total oxygenated compounds & & 40.05 & 26.83 \\
\hline Monoterpenes hydrocarbons & & 21.27 & 18.61 \\
\hline Sesquiterpenes hydrocarbons & & 16.34 & 14.2 \\
\hline
\end{tabular}

Rt: Retention time on varian Elite-5MS column.

$\%$ : Relative area percentage (peak area relative to the total peak).

\subsection{Energy consumption and environmental impact}

The reduced cost of oil extraction is clearly advantageous for SFME method in terms of energy and time saving. HD method required $180 \mathrm{~min}$ to reach a maximum yield of $2.2 \mathrm{mg} / \mathrm{g}$ d.b while $92 \mathrm{~min}$ were sufficient to reach a maximum yield $3.4 \mathrm{mg} / \mathrm{g}$ d.b for SFME. The amounts of water to evaporate were $1 \mathrm{~kg}$ for HD and about $50 \mathrm{~g}$ for SFME. Then, the energy required for performing HD 

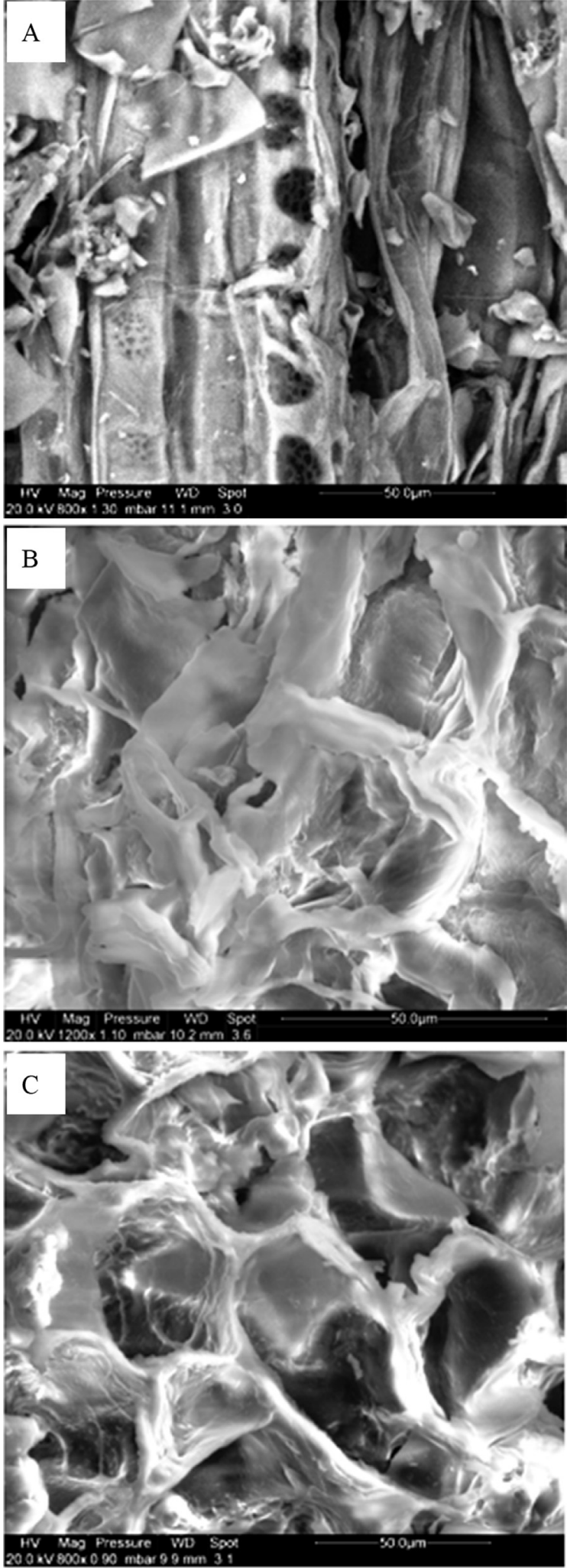

Fig. 5. Scanning Electron microscopy for maritime pine bark waste. (A) Untreated, (B) after HD extraction and (C) after SFME extraction.

and SFME extraction methods were respectively 3,5 $\mathrm{kWh}$ and $1,2 \mathrm{kWh}$ (in optimised conditions). Regarding the environmental impact, the calculated quantity of carbon dioxide rejected in the atmosphere for $\mathrm{HD}$ was from $2619 \mathrm{~g}$ to $3500 \mathrm{~g} \mathrm{CO}_{2}$, largely higher than that of SFME (from $898 \mathrm{~g}$ to $1200 \mathrm{~g} \mathrm{CO}_{2}$ ). These calculations were preformed according to literature provided by the French Nuclear Energy Society (http://www.sfen.org/fr/lenergie-nucleaire/ nucleaire-et-environnement; downloaded on June 25, 2015): to obtain $1 \mathrm{kWh}$ from coal and fuel, respectively $1000 \mathrm{~g}$ and $748 \mathrm{~g}$ of $\mathrm{CO}_{2}$ is rejected in atmosphere during combustion. The GEEN extraction team of Avignon University (Filly et al., 2014; Petigny et al., 2014) recently tested the SFME technique at a pilot plant scale of 150 L capacity, for extraction of essential oil from various biomasses. The authors indicate that microwaves have wideranging large scale commercial applications as processing technology and can provide high returns on capital investment.

\section{Conclusion}

The sustainability of the wood processing industry can be improved through the use of by-products, by adoption of new technologies that maximize process profitability. This study focused on the optimization of SFME extraction process for isolation of oil from wastes of maritime pine wood. The maximum extraction yield was obtained for $803 \mathrm{~W}$ as irradiation power for $92 \mathrm{~min}$ as processing time was $3.34 \%$, higher for that obtained with a conventional method (HD) for which the maximum extraction yield was $2.2 \%$ obtained for $3 \mathrm{~h}$ processing time. Moreover, the oil extracted under microwave irradiation was found to possess an improved antioxidant activity combined with a high quantity of phenolic compounds compared to HD method. Thus we can conclude that SFME is a green extraction method that offers important advantages as short extraction time, low energy input and no requirement of solvent since a comparison of SFME and hydrodistillation showed that it was possible to achieve a higher yield with a reduced extraction time and water volume. As a consequence, SFME exhibited a higher energy efficiency and a reduced environmental impact and thus may prove to be a better alternative to conventional methods. Further investigations are required on large scale SFME processing. Moreover it would be interesting to complete this work by a study on the mass transfer occurring during microwave extraction process as well as by testing the antimicrobial activity of isolated oils.

\section{Acknowledgments}

The authors acknowledge "Région Piotou-Charentes" for the financial support and Ms. Egle Conforto from "Centre Commun d'Analyses" of University of La Rochelle for her assistance in scanning electron microscopy.

\section{References}

Abdelhadi, M., Meullemistre, A., Gelicus, A., Hassani, A., Rezzoug S.A. 2014. Intensification of Hypericum perforatum L. oil isolation by solvent-free microwave extraction. Chem. Eng. Res. Des. 93, 621-631.

Adams, R.P., 2007. Identification of Essential Oil Components by Gas Chromatography/Mass Spectrometry, fourth ed. Allured Publishing Corporation, Carol Stream, IL.

Al-Farsi, M.A., Lee, C.Y., 2008. Optimization of phenolics and dietary fibre extraction from date seeds. Food Chem. 108, 977-985.

Brand-Williams, W., Cuvelier, M.E., Berset, C., 1995. Use of a free radical method to evaluate antioxidant activity. LWT - Food Sci. Technol. 28, 25-30.

Chen, X., Zhang, Y., Zu, Y., Fu, Y., Wang, W., 2011. Composition and biological activities of the essential oil from Schisandra chinensis obtained by solvent-free micro wave extraction. LWT - Food Sci. Technol. 44, 2047-2052.

Dai, J., Mumper, R.J., 2010. Plant phenolics: extraction, analysis and their antioxidant and anticancer properties. Molecules 15, 7313-7352.

Desai, M.A., Parikh, J., 2015. Extraction of essential oil from leaves of lemongrass using microwave radiation: optimization, comparative, kinetic, and biological studies. ACS Sustain. Chem. Eng. 2015 (3), 421-431.

European Pharmacopeia, 2012. On Line Version. http://online6.edqm.eu/ep705/.

Farhat, A., Fabiano-Tixier, A.S., El Maataoui, M., Maignonnat, J.F., Romdhane, M., Chemat, F., 2011. Microwave steam diffusion for extraction of essential oil from 
orange peel: kinetic data, extract's global yield and mechanism. Food Chem. $125,255-261$.

Fernández-Agulló, A., Freire, M.S., González-Álvarez, J., 2015. Effect for the extraction technique on the recovery of bioactive compounds from eucalyptus (Eucalyptus globulus) wood industrial wastes. Ind. Crop Prod. 64, 105-113.

Filly, A., Fernandez, X., Minuti, M., Visinoni, F., Cravotto, G., Chemat, F., 2014. Solvent-free microwave extraction of essential oil from aromatic herbs: from laboratory to pilot and industrial scale. Food Chem. 150, 193-198.

Ghitescu, R.E., Volf, I., Carausu, C., Bühlmann, A.M., Gilca, I.A., Popa, V.I., 2015. Optimization of ultrasound assisted extraction of polyphenols from spruce wood bark. Ultrason. Sonochem. 22, 535-541.

Gholivand, M.B., Piryaei, M.P., Abolghasemi, M.M., 2013. Analysis of volatile oil composition of Citrus aurantium L. by microwave-assisted extraction coupled to headspace solid-phase microextraction with nanoporous based fibers. J. Sep. Sci. 36, 872-877.

González-Centeno, M.R., Comas-Serra, F., Femenia, A., Rosselló, C., Simal, S., 2015. Effect of ultrasound application on aqueous extraction of phenolic compounds and their antioxidant capacity from grape pomace (Vitis vinifera L.): experimental kinetics and modelling. Ultrason. Sonochem. 22, 506-514.

Herzi, N., Camy, S., Bouajila, J., Destrac, P., Romdhane, M., Condoret, J.S., 2013. Supercritical $\mathrm{CO}_{2}$ extraction of Tetraclinis Articulata: chemical composition, antioxidant activity and mathematical modelling. J. Supercrit. Fluid 82, 72-82.

Inan, Ö., Özcan, M.M., Al Juhaimai, F.Y., 2012. Antioxidant effect of mint, laurel and myrtle leaves essential oils on pomegranate kernel, poppy, grape and linseed oil. J. Clean. Prod. 27, 151-154.

Karabegović, I.T., Stojičević, S.S., Todorović, Z.B., Nikolić, N.C., Lazić, M.L., 2014. The effect of different extraction techniques on the composition and antioxidant activity of cherry laurel (Prunus Laurocerasus) leaf and fruit extracts. Ind. Crop Prod. 54, 142-148.

Kim, N.Y., Jang, M.K., Lee, D.G., Yu, K.H., Jang, H., Kim, M., Sung Gu Kim, S.G., Yoo, B.H., Lee, S.H., 2010. Comparison of methods for proanthocyanidin extraction from pine (Pinus densiflora) needles and biological activities of the extracts. Nutr. Res. Pract. 4, 16-22.

Li, H.B., Wong, C.C., Cheng, K.W., Chen, F., 2008. Antioxidant properties in vitro and total phenolic contents in methanol extracts from medicinal plants. LWT Food Sci. Technol. 41, 385-390.

Li, X.J., Wang, W., Luo, M., Li, C.Y., Zu, Y.G., Mu, P.S., Fu, Y.J., 2012. Solvent-free microwave extraction of essential oil from Dryopteris fragrans and evaluation of antioxidant activity. Food Chem. 133, 437-444.

Lue, B.M., Nina Nielsen, S., Jacobsen, C., Hellgren, L., Guo, Z., Xu, X., 2010. Antioxidant properties of modified rutin esters by DPPH, reducing power, iron chelation and human low density lipoprotein assays. Food Chem. 123, 221-230.

Ma, C.H., Yang, L., Zu, Y.G., Liu, T.T., 2012. Optimization of conditions of solvent-free microwave extraction and study on antioxidant capacity of essential oil from Schisandra chinensis (Turcz.) Baill. Food Chem. 134, 2532-2539.

Maimoonaa, A., Naeem, I., Saddiqe, Z., Jameel, K., 2011. A review on biological, nutraceutical and clinical aspects of French maritime pine bark extract. J. Ethnopharmacol. 133, 261-277.

Mellouk, H., Meullemiestre, A., Maache-Rezzoug, Z., Allaf, K., Rezzoug, S.A., 2013. Isolation of volatiles from oak wood (Quercus alba) by thermomechanical process, influence of some processing parameters. Sep. Sci. Technol. 48 1850-1857.

Meullemiestre, A., Kamal, I., Maache-Rezzoug, Z., Chemat, F., Rezzoug, S.A., 2014 Antioxidant activity and total phenolic content of oils extracted from Pinus pinaster sawdust waste. Screening of different innovative isolation techniques. Waste Biomass Valoris. 5, 283-292.

Orhan, I.E., Kartal, M., Gülpinar, A.R., Cos, P., Matheeussen, A., Maes, L., Tasdemir, D., 2013. Assessment of antimicrobial and antiprotozoal activity of the olive oil macerate samples of Hypericum perforatum and their LC-DAD-MS analyses. Food Chem. 138, 870-875.

Orio, L., Cravotto, G., Binello, A., Pignata, G., Nicola, S., Chemat, F., 2012. Hydrodistillation and in situ microwave-generated hydrodistillation of fresh and dried mint leaves: a comparison study. J. Sci. Food Agric. 92, 3085-3090.

Ozkan, A., Erdogan, A., 2011. A comparative evaluation of antioxidant and anticancer activity of essential oil from Origanum onites (Lamiaceae) and its two major phenolic components. Turk. J. Biol. 35, 735-742.

Park, J.S., Lee, G.H., 2011. Volatile compounds and antimicrobial and antioxidant activities of the essential oils of the needles of pinus densiflora and pinus thunbergii. J. Sci. Food Agric. 91, 703-709.

Pavićević, V.P., Marković, M.S., Milojević, S.Ž., Ristić, M.S., Povrenović, D.S., Veljković, V.B., 2015. Microwave-assisted hydrodistillation of juniper berry essential oil: kinetic modeling and chemical composition. J. Chem. Technol Biotechnol. http://dx.doi.org/10.1002/jctb.4653.

Petigny, L., Périno, S., Minuti Visinoni, F., Wajsman, J., Chemat, F., 2014. Simultaneous microwave extraction and separation of volatile and non-volatile organic compounds of Boldo leaves. From lab to industrial scale. Int. J. Mol. Sci. 15, 7183-7198.

Ranic, M., Nikolic, M., Pavlovic, M., Buntic, A., Siler-Marinkovic, S., DimitrijevicBrankovic, S., 2014. Optimization of microwave-assisted extraction of natura antioxidants from spent espresso coffee grounds by response surface methodology. J. Clean. Prod. 80, 69-79.

Rezzoug, S.A., 2009. Optimization of steam extraction of oil from maritime pine needles. J. Wood Chem. Technol. 29, 89-100.

Rodríguez-Rojo, S., Visentin, A., Maestri, D., Cocero, M.J., 2012. Assisted extraction of rosemary antioxidants with green solvents. J. Food Eng. 109, 98-103.

Sarikurkcu, C., Tepe, B., Daferera, D., Polissiou, M., Harmandar, M., 2007. Studies on the antioxidant activity of the essential oil and methanol extract of Marrubium globosum subsp. Globusum (lamiaceae) by three chemical assays. Bioresour. Technol. 99, 4239-4246.

Seabra, I.J., Dias, A.M.A., Braga, M.E.M., De Souza, H.C., 2012. Effect of solvent $\left(\mathrm{CO}_{2} /\right.$ ethanol $/ \mathrm{H}_{2} \mathrm{O}$ ) on the fractionated enhanced solvent extraction of anthocyanins from elderberry pomace. J. Supercrit. Fluid 62, 135-148.

Stashenko, E.E., Martínez, J.R., Cala, M.P., Durán, D.C., Caballero, D., 2013. Chromatographic and mass spectrometric characterization of essential oils and extracts from Lippia (verbenaceae) aromatic plants. J. Sep. Sci. 36, $192-202$.

Zhang, X.L., Guo, Y.S., Wang, C.H., Li, G.Q., Xu, J.J., Chung, H.Y., Ye, W.C., Li, Y.L., Wang, G.C., 2014. Phenolic compounds from Origanum vulgare and their antioxidant and antiviral activities. Food Chem. 152, 300-306. 